HORTSCIENCE 26(7):882-885. 1991.

\title{
High-temperature Conditioning to Delay Internal Breakdown Development in Peaches and Nectarines
}

\author{
George D. Nanos and F. Gordon Mitchell \\ Department of Pomology, University of California, Davis, CA 95616
}

Additional index words. Prunus persica, oxygen, carbon dioxide, storage, controlled atmosphere

\begin{abstract}
Storage at $0 \mathrm{C}$ of 'O'Henry' and 'Fairtime' peaches and 'Red Jim' and 'September Grand' nectarines (Prunus persica L. Batsch) resulted in significantly longer postharvest life than did storage at $5 \mathrm{C}$, due to differences in the development of internal breakdown (IB) symptoms. Conditioning at 20C for 2 days before storage at 0 or 5C generally prolonged the storage life of fruit of these cultivars. The use of elevated $\mathrm{CO}_{2}$ during conditioning helped maintain fruit firmness. Addition of $5 \% \mathrm{CO}_{2}$ to air gave the best results in maintaining fruit firmness and freedom from IB symptoms for up

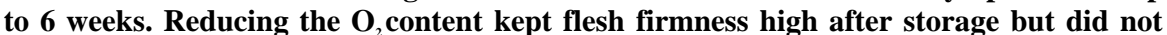
delay the appearance of IB. Conditioning at 30C using various atmospheres was less effective than conditioning at $20 \mathrm{C}$.
\end{abstract}

Transport of peaches and nectarines to distant markets, crop accumulation during certain periods of overproduction, and the need to extend the canning season for clingstone peach cultivars make extended storage desirable. Peaches and nectarines have been satisfactorily stored at low temperatures for 2 to 4 weeks, depending on cultivar (F.G.M., unpublished). The limiting factor of their storability is the development of a form of chilling injury called internal breakdown (IB). IB incidence in stone fruit, which is normally not seen after storage at low temperature, appears after holding fruits at room

Received for publication 23 Mar. 1990. The cost of publishing this paper was defrayed in part by the payment of page charges. Under postal regulations, this paper therefore must be hereby marked advertisement solely to indicate this fact. temperature for a few days following cold storage. Major visual and textural deterioration symptoms due to IB in peaches and nectarines are browning and lack of juiciness (wooliness, dryness, mealiness) of the flesh.

Some treatments have been evaluated for delaying IB development. They include selection of storage temperatures, intermittent warming (Anderson and Penney, 1975) and high-temperature conditioning. It has been reported (Anderson, 1979; F.G.M., unpublished) that $5 \mathrm{C}$ is the worst temperature for storage of stone fruits since it maximizes IB incidence and severity. Storage below $0 \mathrm{C}$ but above the freezing point for stone fruits appears to be beneficial (F.G.M., unpublished).

High-temperature conditioning involves holding fruit at specified temperatures before cold storage. Very good reduction in sensi- 

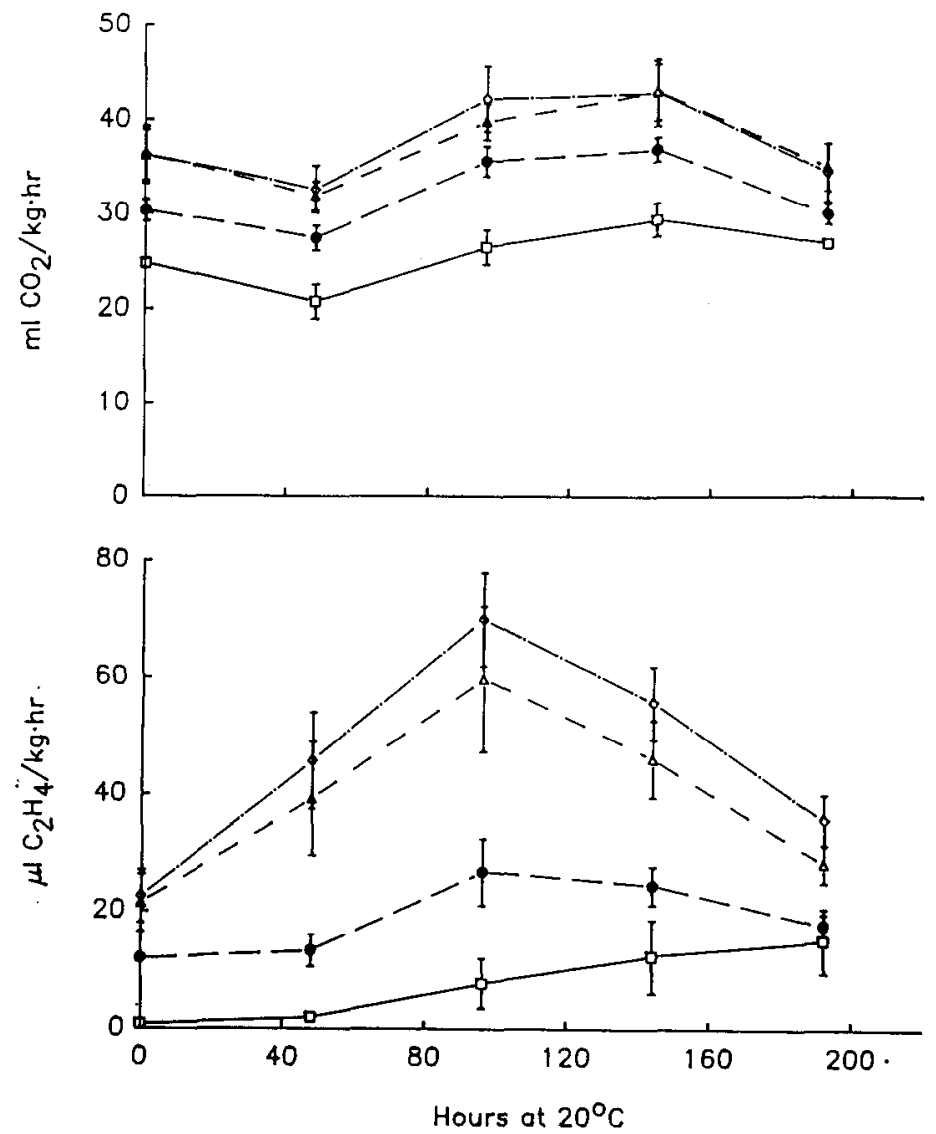

Fig. 1. Effect of various atmospheres applied during 20C conditioning followed by 2 weeks of air storage at $0 \mathrm{C}$ on $\mathrm{CO}_{2}$ and $\mathrm{C}_{2} \mathrm{H}_{4}$ production rates of ' $\mathrm{O}$ 'Henry' peaches during subsequent ripening at $20 \mathrm{C}$. The bars at each point represent $\pm \mathrm{SE}(\mathrm{n}=6)$. Data for peaches that were conditioned in air or $1 \% \mathrm{O}_{2}+5 \% \mathrm{CO}_{2}$ are not shown because the results were similar to those for fruit conditioned in air $+5 \% \mathrm{CO}_{2}$. $0 \mathrm{C}$ control, no conditioning, $\square: ; 20 \mathrm{C}, 2$ days in air $+5 \% \mathrm{CO}_{2}, ;+10 \% \mathrm{CO}_{2}$, $\mathrm{A} ;+15 \% \mathrm{CO}_{2}, \diamond$.

Table 1. Effect of various atmospheres applied during 20C conditioning on flesh firmness of nonripened and ripened (4 days at 20C) 'September Grand' nectarines after 2, 4, and 6 weeks of air storage at $0 \mathrm{C}$.

\begin{tabular}{|c|c|c|c|c|c|c|c|c|}
\hline \multirow{2}{*}{\multicolumn{3}{|c|}{ Conditioning treatments }} & \multicolumn{6}{|c|}{ Flesh firmness $(\mathrm{N})^{\mathrm{z}}$ after air storage at $0 \mathrm{C}$} \\
\hline & & & \multicolumn{6}{|c|}{ Duration of storage (weeks) } \\
\hline$(\%)$ & $(\%)^{2}$ & Days & 2 & 4 & 6 & 2 & 4 & 6 \\
\hline & & & \multicolumn{3}{|c|}{ Nonripened } & \multicolumn{3}{|c|}{ Ripened 4 days at $20 \mathrm{C}$} \\
\hline 21 & 0 & 0 & 37.3 & 45.4 & 48.1 & 7.2 & 13.4 & 15.2 \\
\hline 21 & 0 & 2 & 24.4 & 31.7 & 36.2 & 5.9 & 8.4 & 7.8 \\
\hline 1 & 5 & 2 & 42.4 & 44.1 & 45.7 & 7.2 & 12.3 & 12.0 \\
\hline 20 & 5 & 2 & 32.0 & 42.0 & 39.9 & 6.2 & 9.5 & 8.4 \\
\hline 19 & 10 & 2 & 36.6 & 42.1 & 54.4 & 7.3 & 10.0 & 8.8 \\
\hline 18 & 15 & 2 & 39.5 & 47.5 & 50.2 & 6.6 & 11.1 & 9.2 \\
\hline LSD, & $P=0.05$ & & 5.3 & 6.9 & 6.1 & 1.0 & 1.9 & 2.4 \\
\hline
\end{tabular}

${ }^{2}$ Penetration force was measured with a U.C. firmness tester equipped with an 8-mm-diameter cylindrical plunger. Initial flesh firmness $=42.3 \mathrm{~N}$.

tivity to chilling injury has been reported for conditioned grapefruit (Hatton and Cubbedge, 1975). Guelfat-Reich and Ben-Arie (1966) conditioned 'Elberta' and 'Red Haven' peaches at $26 \mathrm{C}$ for 48 to $72 \mathrm{~h}$ before storage at $0 \mathrm{C}$ and found a 2 -week extension of postharvest life beyond that of control peaches.

Although conditioning of peaches at high temperatures delays the subsequent development of IB, it also causes unacceptable flesh softening. The present study was conducted to determine whether holding peaches lected at random and placed in plastic containers to be treated as described below, and then stored at 0 or $5 \mathrm{C}$ in boxes with loosely closed polyethylene liners.

The fruit were conditioned at either 20 or $30 \mathrm{C}$. Control samples were placed immediately at $0 \mathrm{C}$. Fruit at $20 \mathrm{C}$ were held for 2 days in air, in air enriched with $5 \%, 10 \%$, or $15 \% \mathrm{CO}_{2}$ or in $1 \% \mathrm{O}_{2}+5 \% \mathrm{CO}_{2}$. Fruit at $30 \mathrm{C}$ were held for 1 or 2 days in air, in air enriched with $5 \%$ or $10 \% \mathrm{CO}_{2}$, or in $2 \%$ $\mathrm{O}_{2}+5 \% \mathrm{CO}_{2}$.

The CA conditions were achieved using a continuous-flow gas mixing system. The concentrations of $\mathrm{O}_{2}$ and $\mathrm{CO}_{2}$ were monitored using a Carle gas chromatography (Model 111, Carle Instruments, Anaheim, Calif.) equipped with a thermal conductivity detector. Gas concentrations were maintained within $\pm 0.2 \%$ of the desired concentrations. After application of the conditioning treatments, the fruit were stored at 0 or $5 \mathrm{C}$.

Samples were evaluated for quality (15 fruit) and internal breakdown incidence (21 fruit) following storage at $0 \mathrm{C}$ for $2,3,4,5$, and 6 weeks for those conditioned at 20C and after $3,4.5$, and 6 weeks for those conditioned at $30 \mathrm{C}$. Half of the fruit were evaluated for quality after $3 \mathrm{~h}$ at room temperature, the rest after ripening for 3 or 4 days at $20 \mathrm{C}$.

A Gardner XL-23 Tristimulus colorimeter (Gardner Laboratory, Bethesda, Md.) was used to measure the background color (green disappearance), expressed as the 'a' value, in a representative area of the fruit surface (without red coloration whenever possible), and to evaluate flesh color after removing the skin from one cheek. Skin was then removed from the second cheek, and two flesh firmness measurements per fruit were made using a U.C. firmness tester (Western Industrial Supply, San Francisco, Calif.) with an 8-mm tip. The samples were subsequently randomized among three subsamples. A wedge was cut from each fruit, the wedges of each subsample were combined, and the juice was extracted and filtered through cheesecloth with a hand press. The soluble solids content of this juice was measured using an American Optical refractometer with automatic temperature compensation. A 4-g sample of the same juice was diluted with $20 \mathrm{ml}$ deionized water; the initial $\mathrm{pH}$ was measured, and the sample was titrated to an end point of 8.2, using $0.1 \mathrm{~N} \mathrm{NaOH}$. Titratable acidity was calculated as percent malic acid.

Respiration and ethylene production of six randomly selected fruit were determined at the first sampling period. The fruit were placed individually in jars ventilated with a flowing air stream of $\approx 2.5$ liter $\cdot \mathrm{h}^{-1}$. Gas samples were taken from the outlets of the jars at intervals of $\approx 20 \mathrm{~h}$. Carbon dioxide concentration in the gas samples was measured with a Horiba Infrared $\mathrm{CO}_{2}$ gas analyzer (Model SX-2, PIR-2000R; Horiba Instruments, Irvine, Calif.), and $\mathrm{C}_{2} \mathrm{H}_{4}$ concentration was measured with a Carle gas chromatography (Model 211, Carle Instruments) equipped with a flame ionization detector. 


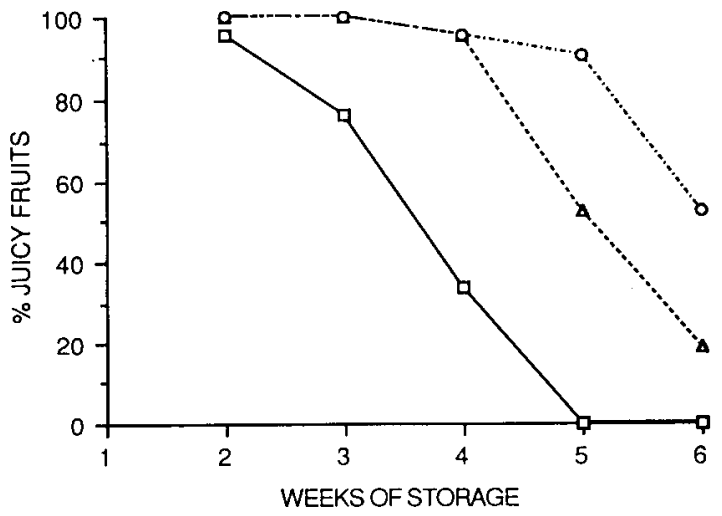

Fig. 2. Effect of $5 \% \mathrm{CO}_{2}$ applied during 20C conditioning followed by 2 to 6 weeks of air storage at $0 \mathrm{C}$ on flesh juiciness of 'Fairtime' peaches. Data points are significantly different when they differ by 10 percentage units or more. The data were analyzed as categorical data (Johnson and Bhattacharyya, 1986). 0C control, no conditioning, $\square ; 20 \mathrm{C}, 2$ days in air, $\triangle$; 20C, 2 days in air $+5 \%$ $\mathrm{CO}_{2}, \mathrm{O}$.

Table 2. Length of time (in weeks) beyond which incidence of flesh browning and lack of juiciness became unacceptable ${ }^{z}$ in fruits stored at 0 or $5 \mathrm{C}$ following the conditioning treatments ${ }^{y}$ used for each cultivar.

\begin{tabular}{|c|c|c|c|c|}
\hline \multirow{5}{*}{$\begin{array}{l}\text { Conditioning } \\
\text { temp and cultivar }\end{array}$} & \multicolumn{4}{|c|}{ Postharvest life (weeks) } \\
\hline & \multicolumn{4}{|c|}{ Basis } \\
\hline & \multicolumn{2}{|c|}{ Flesh browning } & \multicolumn{2}{|c|}{ Juiciness } \\
\hline & \multicolumn{4}{|c|}{ Storage temp $\left({ }^{\circ} \mathrm{C}\right)$} \\
\hline & 0 & 5 & 0 & 5 \\
\hline \multicolumn{5}{|l|}{$20 \mathrm{C}$} \\
\hline O'Henry & 6 & 3 & 6 & 2 \\
\hline Red Jim & 6 & 4 & 6 & 4 \\
\hline September Grand & 6 & 3 & 6 & 3 \\
\hline Fairtime & 5 & $<2$ & 5 & 2 \\
\hline \multicolumn{5}{|l|}{$30 \mathrm{C}$} \\
\hline O'Henry & 4.5 & 3 & 6 & 3 \\
\hline Red Jim & 6 & 3 & 6 & 3 \\
\hline September Grand & 6 & $<3$ & 6 & 3 \\
\hline Fairtime & 4.5 & $<3$ & 4.5 & $<3$ \\
\hline
\end{tabular}

${ }^{z} A$ treatment was unacceptable when $>15 \%$ of the fruits showed flesh browning and $<85 \%$ of the fruits were juicy. Evaluations were conducted subjectively by two panelists.

${ }^{y} \mathrm{At} 20 \mathrm{C}$ : Conditioning for 2 days in air or $5 \% \mathrm{CO}_{2}$. At $30 \mathrm{C}$ : Conditioning for 1 day in air or 2 days in $5 \% \mathrm{CO}_{2}$.

At each sampling time, fruit from both storage temperatures $(0$ and $5 \mathrm{C})$ were ripened for 5 days at $20 \mathrm{C}$, then evaluated subjectively for incidence and severity of symptoms of internal breakdown. Symptoms measured were: browning, juiciness/mealiness, hardness, and bleeding. These observations were made on the mesocarp and the area around the pit after the fruit were cut transversely to the plane of the suture. Decay incidence was negligible and not evaluated.

Analysis of variance using the MSTAT-C program (Michigan State Univ., East Lansing) was performed over treatment. Least significant difference values at $P=0.05$ are presented. Otherwise, standard error bars are shown.

High $\mathrm{CO}_{2}$ in the conditioning atmosphere at $20 \mathrm{C}$ did not retard the loss of flesh greenness seen after cool storage. The decrease was, however, prevented by low $\mathrm{O}_{2}$ in the conditioning atmosphere. A similar pattern was seen for the fruit conditioned at $30 \mathrm{C}$ (data not shown). This result agrees with the observations from storage of plums in $2 \%$ $\mathrm{O}_{2}+5 \% \mathrm{CO}_{2}$ at 10 or $20 \mathrm{C}$ (A.A. Kader, unpublished). Thus, lowering the $\mathrm{O}_{2}$ concentration of the atmosphere appears more important than elevating $\mathrm{CO}_{2}$ in inhibiting changes in internal color.

Fruit conditioned at $20 \mathrm{C}$ (Table 1) or 30C (data not shown) in air were softest. After 6 weeks of storage, the firmness of fruit in the $0 \mathrm{C}$ control and those conditioned in $1 \% \mathrm{O}_{2}$ $+5 \% \mathrm{CO}_{2}$ was very close to the initial readings. Thus, softening was reduced more by conditioning in $1 \% \mathrm{O}_{2}$ than by conditioning in air enriched with $5 \%, 10 \%$, or $15 \% \mathrm{CO}_{2}$.

Flesh firmness measurements taken after ripening showed normal softening of fruit in all treatments after 2 or 3 weeks of storage. After 4 weeks of storage, fruit in the $0 \mathrm{C}$ control and those conditioned at $20 \mathrm{C}$ with $1 \% \mathrm{O}_{2}+5 \% \mathrm{CO}_{2}$ had softened less than the other samples (Table 1). This retention of flesh firmness is a typical IB symptom, and these treatments (mainly the unconditioned, OC control) also showed high levels of flesh browning and mealiness typical of IB. Similarly, the retention of flesh firmness was observed for the above treatments with three (out of the four) test cultivars
('O'Henry', 'September Grand', and 'Fairtime') in both 20 and $30 \mathrm{C}$ conditioning experiments.

Fruit of 'O'Henry' showed elevated $\mathrm{CO}_{2}$ and $\mathrm{C}_{2} \mathrm{H}_{4}$ production rates following conditioning in air enriched with 5\% (except at $192 \mathrm{~h}$ for ethylene), $10 \%$, or $15 \% \mathrm{CO}_{2}$ at 20C (Fig. 1) and $10 \%$ at 30C (data not shown). 'Red Jim' nectarines responded similarly (data not shown). Because these measurements were taken 2 or 3 weeks after conditioning, they were not due to the release of $\mathrm{CO}$, that was absorbed by the tissue during conditioning. Rather, this appears to be an injury response from exposure to the $10 \%$ and $15 \% \mathrm{CO}_{2}$ levels at $20 \mathrm{C}$ and $10 \%$ at $30 \mathrm{C}$. The $0 \mathrm{C}$ control fruit showed the lowest rates of $\mathrm{CO}_{2}$ and $\mathrm{C}_{2} \mathrm{H}_{4}$ production. Fruit treated in air enriched with $5 \% \mathrm{CO}_{2}$ showed $\mathrm{CO}_{2}$ and $\mathrm{C}_{2} \mathrm{H}_{2}$ production rates similar to airtreated fruit, and higher than the nonconditioned, 0C control. These elevated production rates can be attributed to advanced ripening. No other consistent differences between treatments were observed in the four cultivars tested.

'Red Jim' nectarines failed to ripen after 6 weeks of storage at $0 \mathrm{C}$, but no flesh browning symptoms developed. Fruit stored at $5 \mathrm{C}$ for 6 weeks, however, ripened and developed IB symptoms (data not shown). The fruit of this cultivar showed very low $\mathrm{CO}_{2}$ and $\mathrm{C}_{2} \mathrm{H}_{4}$ production rates compared with the other cultivars. The slow ripening characteristics of this cultivar might permit handling at $10 \mathrm{C}$ to avoid IB symptom development (A.A. Kader, unpublished).

Flesh browning development (an IB symptom) made the $0 \mathrm{C}$ control fruit of 'Fairtime' and 'September Grand' unsalable after 3 and 6 weeks of storage, respectively. This result is consistent with previous observations that 'Fairtime' peaches are very susceptible to flesh browning (F.G.M., unpublished). Finally, fruit from all conditioning treatments (except those in $1 \% \mathrm{O}_{2}+$ $5 \% \mathrm{CO}_{2}$ ) showed consistently lower levels of flesh browning than the nonconditioned, OC control fruit.

'Fairtime' peaches also showed their high susceptibility to IB as indicated by lack of juiciness (Fig. 2). The unconditioned OC control fruit had begun to lose juiciness after 3 weeks of storage, while some fruit conditioned with high $\mathrm{CO}_{2}$ were still acceptably juicy after 5 weeks of storage. The conditioning treatments generally increased the storage life of the other three cultivars, but there were no consistently significant differences among treatments.

Storage at $0 \mathrm{C}$ extended the postharvest life of fruit for 2 to 3 weeks beyond that achieved at $5 \mathrm{C}$, based on measurements of flesh browning and juiciness (Table 2). This result confirms previous results on stone fruits (Anderson, 1979; F.G.M., unpublished).

In conclusion, flesh softening resulting from high-temperature conditioning was satisfactorily controlled by using air $+5 \% \mathrm{CO}_{2}$ as the conditioning atmosphere. Use of air + $10 \%$ or $15 \% \mathrm{CO}_{2}$ resulted in $\mathrm{CO}_{2}$ injury (as manifested by increased $\mathrm{CO}_{2}$ and $\mathrm{C}_{2} \mathrm{H}_{4}$ pro- 
duction rates) for 'O'Henry' peaches and 'Red Jim' nectarines. The combination of low $\mathrm{O}_{2}$ and elevated $\mathrm{CO}_{2}$ during conditioning was more effective than elevated $\mathrm{CO}_{2}$ alone in arresting ripening (flesh softening and degreening) but did not delay IB development satisfactorily. The test cultivars showed less benefit from the various controlled atmosphere conditioning treatments when conditioned at $30 \mathrm{C}$ than at $20 \mathrm{C}$. For the cultivars tested, conditioning fruit at $20 \mathrm{C}$ for 2 days in air $+5 \% \mathrm{CO}_{2}$ followed by air storage at OC can substantially delay the onset of IB and avoid unacceptable flesh softening. It was possible by using this treatment to achieve a 6-week postharvest life with three out of the four test cultivars and a 5-week postharvest life with 'Fairtime' peaches.

\section{Literature Cited}

Anderson, R.E. 1979. The influence of storage temperature and warming during storage on peach and nectarine fruit quality. J. Amer. Soc. Hort. Sci. 104:459-461.

Anderson, R.E. and R.W. Penney. 1975. Intermittent warming of peaches and nectarines stored in a controlled atmosphere or air. J. Amer. Soc. Hort. Sci. 100:151-153.

Guelfat-Reich, S. and R. Ben-Arie. 1966. Effect of delayed storage and the stage of maturity at harvest on the keeping quality of peaches in Israel. Israel J. Agr. Res. 16:163-170.

Johnson, R. and G. Bhattacharyya. 1986. Statistics: Principles and methods. Wiley, New York. p. $428-456$.

Hatton, T.T. and R.H. Cubbedge. 1975. Effects of prestorage carbon dioxide treatments and delayed storage on chilling injury of "Marsh" grapefruit. Proc. Fla. State Hort. Soc. 88:335338. 